\title{
Determinants of Private Saving Level: Evidence from Turkey
}

Mevlüt TATLIYER, Department of Economics and Finance, School of Business and Management Sciences, Medipol University, Turkey; e-mail: mtatliyer@medipol.edu.tr

\section{Özel Tasarruf Düzeyinin Belirleyicileri: Türkiye Örneği}

\begin{abstract}
This paper attempts to ascertain the determinants of private saving level in Turkey. We implemented OLS estimations and constructed a VEC model in order to circumvent possible endogeneity bias. Dataset was acquired from the World Bank, Turkish Central Bank and Turkish Statistical Institute. The period examined is from 1988 to 2010. This research found that a) private and public saving rates are partly complementary to each other; b) higher inflation rates and lower levels of social security tend to increase private saving rate because of higher uncertainty; c) easing credit constraints tends to decrease private saving; d) favorable terms of trade promote private saving by increasing income; and e) current account balance influence private saving positively.
\end{abstract}

Keywords : Private Saving, Public Saving, VECM.

JEL Classification Codes : D14, D91, E21.

\section{$\ddot{\mathbf{O} z}$}

$\mathrm{Bu}$ çalışma Türkiye'de özel tasarruf seviyesini belirleyen unsurları ortaya çıkarmaya çalışmaktadır. Çalışmada EKK tahminleri yapılmış ve muhtemel bir içsellik hatasından kaçınabilmek için de VEC modeli oluşturulmuştur. Veri seti Dünya Bankas1, TCMB ve TÜİK'ten elde edilmiştir. Çalışmanın periyodu 1988-2010'dur. Çalışmada elde edilen sonuçlar ise şu şekildedir: a) Özel ve kamu tasarruf seviyeleri kısmen birbirini tamamlayıcıdır; b) yüksek enflasyon oranları ve düşük sosyal güvenlik seviyeleri yüksek belirsizlikten dolayı özel tasarruf seviyesini arttırma eğilimindedir; c) kredi kısıtlarının hafifletilmesi özel tasarrufu düşürme eğilimindedir; d) uygun dış ticaret hadleri gelir düzeyini arttırarak özel tasarrufu yükseltmektedir ve e) ödemeler bilançosu özel tasarrufu pozitif bir şekilde etkilemektedir.

Anahtar Sözcükler ： Özel Tasarruf, Kamu Tasarrufu, VECM. 


\section{Introduction}

Private saving behavior and the relationship between private saving and economic growth have long been debated in the economic literature. Prior to the Great Depression and Keynes' General Theory, saving was regarded as a source of productive capital and great importance was given to thrift. However, thanks to the economic turmoil of the 1930s, Keynes (1936) changed the way saving was perceived from being a source of investment and capital to being a drain on effective demand and a hidden enemy of social welfare (Modigliani, 1986).

Keynes (1936) believed that rising incomes increase consumption to only a limited extent, since private saving is allegedly a luxury good. In his own words: "The fundamental psychological law (...) is that men are disposed, as a rule and on the average, to increase their consumption as their income increases, but not by as much as the increase in their income" (p. 96).

However, in the 1940s, saving more or less regained its original status. This was due to a number of important empirical studies, which revealed that although per capita income had almost tripled in the US, saving rates had changed little between the middle of the nineteenth century to the 1930s (Kuznets, 1946; Modigliani, 1986). Clearly, these findings were at odds with the dominant understanding of saving in that period.

The evidence from these studies inspired several saving theories, two of which stood out in particular: Friedman's Permanent Income Hypothesis $(P I H)$ and Modigliani and Brumberg's Life Cycle Hypothesis $(\mathrm{LCH})$.

In $P I H$, Friedman (1957) divided income into two; permanent income, which is expected long-term income, and transitory income, which occurs by chance. Friedman also identified two categories of consumption; permanent consumption and transitory consumption. While transitory consumption exclusively depends on transitory income, permanent consumption depends on interest rates, the ratio of nonhuman wealth to income (which represents the relative importance of property and nonproperty income), and consumer preferences about consumption and saving, as well as the level of permanent income. In Friedman's approach, the ratio of permanent consumption to permanent income is independent of the level of permanent income; it depends on the aforementioned factors. That is, the private saving rate is more or less stable and does not depend on the level of permanent income (Friedman, 1957).

In a similar vein, according to Modigliani and Brumberg's $\mathrm{LCH}$, the consumer's consumption is not simply based on their current income, but on their expected lifelong income. In this context, $L C H$ stresses the life stage sensitivity of consumption; that is, people spend more than their current income when they are out of the labor force and spend less than their current income when they are working (Modigliani \& Bartel, 1987). 
To put it another way, people generally save when they are working and dissave when they are not. Hence, $\mathrm{LCH}$ implies that the private saving rate does not depend on per capita income level, so the differences in private saving rates between countries can be explained by life cycle behavior and long-run economic growth rates (Modigliani, 1986).

The perceived importance of saving increased further with a seminal paper by Feldstein and Horioka (1980), which reported that saving and investment levels were closely related in 21 developed countries. That is, higher saving rates in a country were typically accompanied by greater investment, and vice versa. This came as a surprise and dubbed the Feldstein-Horioka puzzle, because, in a global world, countries have access to international capital markets, so they should not be dependent on domestic savings for investment. Numerous papers followed up on Feldstein and Horioka (1980) work, more or less confirming that saving is the most important factor determining a country's investment, though the subject is highly controversial.

The implication that saving is a constraint to investment resulted in much-increased attention to the topic of saving in the relevant literature, especially because of the wellestablished direct link between investment and economic growth. Since then, along with the increasing divergence between countries in terms of saving rates, numerous papers have been devoted to the saving behavior of countries.

However, despite the burgeoning literature regarding saving behavior, the main determinants of private saving and their net effects have yet to be agreed on conclusively. As such, although the literature regarding saving behavior is extensive and the potential factors affecting saving decisions well known, there is significant disagreement about the significance and even the sign of (some of these) variables. This is not hugely surprising in relation to the empirical literature, because the findings obtained by any given study are highly dependent on the estimation method employed (e.g., time-series or cross-sectional estimation), as well as the time period and country/countries analyzed (Masson \& Bayoumi \& Samiei, 1998).

For instance, demographic variables like dependency ratio, or economic variables like GDP per capita, are typically found to have a more significant effect on private saving level when a cross-sectional method is used. This is because these kinds of variables tend to change very slowly, especially when the existing magnitude of the variable is considered. Time-series analysis therefore tends to underestimate the role of these variables, while crosssectional analysis may inflate their effect.

Likewise, the country/countries chosen for empirical studies also seem to affect the perceived significance of potential determinants of private saving. For instance, demographic variables are generally shown to have a significant effect on saving behavior in time-series analyses of Japan, but this is not the case for the United States (Masson et al., 1998). 
Moreover, variables such as real interest rate and financial depth theoretically have an ambiguous effect on private saving rate, giving rise to important disagreements even about the sign of these kinds of variables. One can argue that idiosyncratic factors play significant roles in the magnitude and even the sign of these kinds of variables. Some factors, however, such as public saving, have been consistently found to affect saving behavior in various studies.

On the other hand, most of the studies in this strand of literature have focused on saving behavior in specific regions and country groups, with far less interest on specific countries. Although focusing on specific regions and country groups provides important insights into the nature of saving behavior, nationally idiosyncratic factors and differences in historical experiences among countries, which can play important roles (see Jermias \& Yigit, 2013) in the eventual fate of the saving rate, can be undervalued and even lost in the process when cross-section analyses are employed.

Moreover, most of cross-section analyses regarding saving behavior suffer from inaccuracies in and even lack of data (Ozcan \& Gunay \& Ertac, 2003) and as the number of countries increase in the cross-section analyses this problem multiplies and can give way for incorrect findings. While specific country analysis can suffer from these problems as well; analyses of single countries, which have relatively healthier data sets that spanning relatively longer time periods, can provide more robust understanding of saving behavior.

In that sense, Turkey, which is an emerging country with the seventeenth largest economy in the world, could be a good candidate for the analysis of a specific country for saving behavior. Firstly, Turkish economy rapidly changed structure in the 2000s (private saving rate has declined substantially and almost halved to some 12 percent, inflation rate shrank sevenfold to one-digit and current account balance has deteriorated severely in the 2000s, not to mention rapid expansion of the financial sector) and analyzing this emerging country can shed important lights on the highly complex relationship between saving rate and its determinants.

Secondly, Turkey has relatively accurate and complete data sets spanning relatively a long period for the analysis of saving rate and its determinants. However, while there are relatively few studies for specific country analysis, among them Turkey attracted much less interest regarding saving behavior. Thus, this paper tries to fill in this gap and focuses on saving behavior in Turkey in order to shed light on the relationship between private saving rate and other economic variables.

Recent empirical studies regarding saving behavior in Turkey include the work of Van Rijckeghem (2010) and Matur, Sabuncu, and Bahçeci (2012), covering the periods of 1988-2009 and 1980-2008, respectively.

Van Rijckeghem (2010) reports that only government saving rate and government overall balance have a significant (negative) impact on private saving rate in Turkey. This is a very curious finding, since saving rate seems highly associated with other fundamental 
economic variables and it is highly improbable that only government has a saying in the level of private saving rate.

Matur et al. (2012) find seven determinants of private saving in Turkey. According to them, per capita income, inflation rate and real interest rate have positive influence on private saving. However, the coefficients of these variables are relatively low: 0.21 for per capita income, 0.15 for real interest rate and only 0.04 for inflation rate. This means that while de jure these variables do influence private saving, they de facto do not have much saying regarding private saving. This is especially true for the coefficient of inflation rate. On the other hand, public saving rate, per capita income growth, private credit to GDP ratio and old dependency ratio affect private saving rate negatively. However, while the coefficients of public saving rate (-0.38), per capita income growth $(-0.15)$ and private credit to GDP ratio $(-0.37)$ are relatively plausible, the coefficient of old dependency ratio $(-4.64)$ seems implausibly high.

The rest of the paper is organized as follows. In the next section, potential determinants of saving in the literature are discussed. Section III puts Turkish private saving rate in global context. Section IV introduces private saving model. In Section V, empirical analysis is implemented. In the last section findings are discussed.

\section{Literature Review: Potential Determinants of Saving}

In this section, the potential determinants of private saving identified in the literature are briefly outlined to help develop a model of saving behavior.

\subsection{Inertia}

Several studies have found that inertia had an influence on private saving rates, wherein the current period's private saving rate is affected by that of the previous period. This means that countries with a high/low private saving rate tend not to change in the near future. For instance, Loayza, Schmidt-Hebbel, and Servén (2000a) report that, even when controlled for other relevant factors, saving rates from one period to the next are significantly correlated with each other. Hence, including inertia in a model of saving behavior will make it possible to see whether past saving rates really have an effect on current saving rates.

\subsection{Income Level and Income Growth}

There is a strong consensus in the literature that saving leads to economic growth and that economic growth promotes saving, indicating a positive two-way relationship between income and saving rates (Attanasio \& Picci \& Scorcu, 2000; Carroll \& Weil, 1994; Hondroyiannis, 2006; Loayza et al., 2000a; Mohan, 2006). This relationship is also consistent with Keynesian consumption theory, which suggests that the higher the income, the higher the marginal propensity to save. Intuitively, the poor are more likely to save less than the rich does, because the income of the poor either hardly meets their basic needs or 
leaves much less for them to save than is available to the rich. Indeed, several studies have revealed that richer countries tend to have a higher private saving rate.

However, while there is a well-established theoretical and well-supported empirical link between income levels and private saving rates, the effect of income growth on private saving rate is theoretically uncertain because of its conflicting influence on saving behavior. According to Modigliani (1986), higher income growth rates alter households' expectations regarding future income levels and thus may increase their consumption and reduce private saving. Conversely, if this increase in income is concentrated on relatively rich households, then growing income can also translate into increased private saving rates (Ramajo \& García \& Ferré, 2006). It is therefore very hard to ascertain the net effect of income growth on private saving rates, with further theoretical and empirical analysis required to reveal the nature of this relationship.

\subsection{Real Interest Rate}

The effect of real interest rate on private saving rate is also ambiguous. While income effect has a negative impact on private saving rate, intertemporal substitution effect has a positive impact on it. Most empirical studies have found real interest rates to have a statistically insignificant effect on private saving rates, some have found a significant but weak relationship between the two (See Edwards, 1996; Loayza \& Schmidt-Hebbel \& Servén, 2000b).

\subsection{Borrowing Constraints and Monetization Level}

Theoretically borrowing constraints increase private saving rates because people will be more inclined to save for either unexpected expenses or anticipated future consumption, such as buying a house (See Jappelli \& Pagano, 1989). In most industrialized countries and later in emerging countries, such as Turkey, borrowing constraints have been loosened significantly over recent decades. Increased access to credit should theoretically encourage households to save less, as has been shown in studies conducted in both developing and industrialized countries (Bayoumi, 1993; Hondroyiannis, 2006; Zeldes, 1989).

In addition, the degree of monetization in an economy can also impact private saving levels. If monetization is interpreted as a measure of financial depth and sophistication, then there should be a positive relationship between monetization and private saving levels. However, if monetization is taken as a gauge of the extent of borrowing constraints, which applies more to developing countries than industrialized ones, the expected sign is negative (Edwards, 1996).

In this paper, the ratio of consumer credit to GDP is used as a proxy for borrowing constraint and M2 is adopted as a proxy for monetization level. These were chosen because, at the same time as the Turkish private saving rate declined steeply in the 2000s, consumer credit availability and monetization increased sharply in the country. 
Tatliyer, M. (2017), "Determinants of Private Saving Level:

Evidence from Turkey", Sosyoekonomi, Vol. 25(32), 149-167.

\subsection{Demographics}

Demographics are posited to have an overarching effect on saving behavior, as is stressed in life-cycle models. This is because people tend to save when they are middle-aged and dissave when they are young and old. If this is the case, a change in the age structure of the population should have an effect on overall saving behavior.

Indeed, most studies show that countries with a higher share of young and old people within the population tend to save less. However, as mentioned above, this phenomenon is more prominent in cross-sectional analyses than time-series analyses, because demographic variables change very slowly (See Agrawal \& Sahoo \& Dash, 2009; Bosworth \& ChodorowReich, 2007; Kim \& Lee, 2008; Li \& Zhang \& Zhang, 2007; Lührmann, 2003).

\subsection{Uncertainty}

Increased uncertainty will typically encourage precautionary saving of all households across the board, because uncertainty creates insecurity, so people save more in order to hedge against this. There are three main forms of economic insecurity in the literature: high inflation rates, conceived as a form of monetary uncertainty, and levels of social security and urbanization, which are classified as societal uncertainties. Higher inflation rates increase uncertainty in the economy, which makes people save more, as has been shown in various empirical studies. It is worth noting, however, that while increased inflation is generally found to have a statistically significant positive effect on saving in countries with relatively high inflation rates, in some relatively low inflation countries, empirical studies have found no statistically significant effect (Bérubé \& Côté, 2000; Hüfner \& Koske, 2010; Schmidt-Hebbel \& Webb \& Corsetti, 1992).

In addition, since comprehensive social security eases the strain of uncertainty on individuals, it will generally decrease precautionary saving, theoretically. This is supported by the results of most studies conducted on saving behavior. In addition, higher levels of urbanization are also associated with lower precautionary saving in the literature, since more urbanization level is associated with easier access to social security and financial resources, among others (Feldstein, 1980; Horioka \& Yin, 2009; Modigliani \& Sterling, 1981).

\subsection{Public Saving}

Public and private saving are thought to be partially complementary to each other. Moreover, government budget balance is a direct indicator of the saving behavior of the government, with a budget deficit indicating government dissaving and generally accompanied by increased private saving. This means that increases in public saving are accompanied by decreases in private saving, and vice versa (Hondroyiannis, 2006; Masson et al., 1998; Matur et al., 2012; Schrooten \& Stephan, 2003). 


\subsection{Foreign Trade}

In an open economy, favorable terms of trade should have a positive impact on private saving levels, since improvements in a country's terms of trade should increase income levels (Hevia, 2010).

Current account balance can also have an effect on private saving levels, although this relationship is not straightforward. Rising current account deficit in a country is typically accompanied by declining private saving levels. However, current account balance itself is determined by more fundamental factors such as real effective exchange rate, so the resulting negative relationship between current account deficit and private saving level may be a case of correlation rather than causation (Loayza et al., 2000b).

\section{Stylized Facts Regarding Private Saving}

Private saving rate in Turkey decreased substantially in the 2000s after hovering around well over $20 \%$ in the 1990s. Moreover, in the former period, private saving rate had also markedly been higher than private investment rate. However, in the latter period, these two rates have converged to each other significantly. To put into perspective, both public saving rate and public investment rate were markedly lower than that of private ones, though the former was erratic while the latter was more or less steady around $5 \%$.

Figure: 1

\section{Saving and Investment Rates in Turkey}

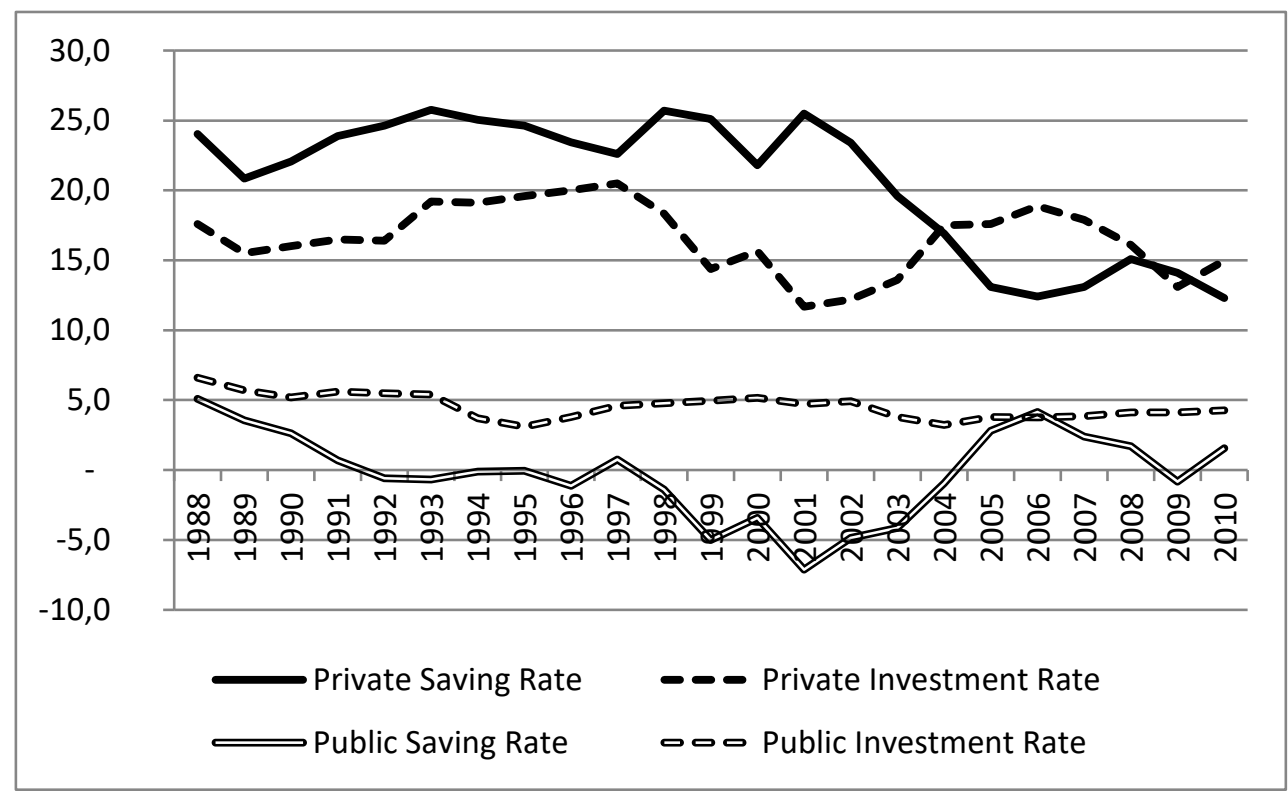

Source: Ministry of Development. 
It is interesting to note that world private saving rate remained at around $20 \%$ with a little variation in the 1990s and 2000s, unlike Turkey who experienced a sharp decline particularly in the first half of the 2000s. On the other hand, world public saving rate has been around $2-3 \%$ in the $1990 \mathrm{~s}$, which was followed by a sharp increase to around $6 \%$ in the 2000s, only falling again as a result of the global financial crisis (Grigoli, Herman et al. 2014), just like in Turkey where public saving rate first increased substantially from around negative 5\% to positive 5\% between 2001 and 2006, and then decreased steeply with the onset of the global financial crisis.

The average private saving rate in industrialized economies did not fluctuate much from the 1980 s to the 2000 s with an average of $27.2 \%$. Moreover, average private saving rate of emerging Asian economies increased steadily, albeit slowly, from over $25 \%$ to around $34 \%$ between the 1980 s and 2000s. On the other hand, low-income developing countries fared considerably worse in terms of private saving rate than that of other countries with around $10 \%$ in the 1990s and around 14\% in the 2000s (Grigoli, Herman et al. 2014).

The evolution of private saving rate for different country groups shows that while Turkish private saving rate had been above the world average and close to the level of industrialized countries in the 1990s, it decreased markedly to a level well below the world average and tantamount to the level of low-income developing countries in the 2000s. However, to put Turkey better into context, one should note that several industrialized and emerging countries had and have considerably low levels of private or household saving rate. For example, the US household saving rate was only $4.6 \%$ in the 2000 s on average, while it was negative 2.2\% for New Zealand. Moreover, household saving rate of Chile was around just only $12.5 \%$ as of 2003 , only decreasing further to $8.3 \%$ as of 2010 . Another emerging country, Mexico fared similar. Mexican household saving rate decreased from 10.1 to $8.8 \%$ in the same period. When all these taken into account, it becomes relatively clear that the Turkish situation in terms of private saving rate has deteriorated markedly in the 2000s, though there are several emerging and industrialized countries that fared similar to and worse than Turkey.

\section{The Model}

Based upon the potential determinants of private saving identified in the literature, a model of saving was developed using the following formula:

$$
\begin{aligned}
& S_{t}=\beta_{0} I G_{t}+\beta_{1} I L_{t}+\beta_{2} R_{t}+\beta_{3} C_{t}+\beta_{4} M 2_{t}+\beta_{5} O D_{t}+\beta_{6} Y D_{t}+\beta_{7} U_{t}+\beta_{8} I_{t}+ \\
& \beta_{9} S S_{t}+\beta_{10} P S_{t}+\beta_{11} C A_{t}+\beta_{12} T T_{t}
\end{aligned}
$$

where, $S_{t}$ denotes private saving rate, $I G_{t}$ corresponds to income growth rate (proxied by GDP per capita growth rate), $I L_{t}$ is income level (proxied by GDP per capita), $R_{t}$ denotes real interest rate, $C_{t}$ is consumer credit level to GDP ratio, $M 2_{t}$ is $\mathrm{M} 2$ to GDP ratio, $O D_{t}$ corresponds to old dependency ratio, $Y D_{t}$ is youth dependency ratio, $U_{t}$ is urbanization rate, $L E_{t}$ denotes life expectancy, $I_{t}$ is inflation rate, $S S_{t}$ denotes social security level (proxied by 
social security expenditures to GDP ratio), $P S_{t}$ corresponds to public saving rate, $C A_{t}$ denotes current account balance, and $T T_{t}$ is terms of trade.

The population surveys ran by the Turkish Statistical Institute (TSI) had been implemented at five-year intervals prior to 2000, then at one-year intervals since. For the purposes of this research, the five-year data points have been extrapolated.

All the data employed in this study were acquired from the World Bank, Central Bank of The Republic of Turkey, Ministry of Development and TSI. The period examined is from 1988 to 2010.

\section{Empirical Analysis}

In the model, some of the explanatory variables such as income growth and income level seem to be jointly determined with private saving rate. Therefore, we must deal with this endogeneity problem. Instrumental Variables (IV) is a commonly used technique in handling endogeneity/simultaneity problem in the literature. However, while theoretically IV approach seems the best technique in dealing with the endogeneity problem; its usefulness is limited in practice, because finding appropriate instrumental variables for the explanatory variables is not an easy task (Arellano \& Bover, 1995), which was also the main problem in our model, and specifying viable instrumental variables for explanatory variables of private saving rate, which are possibly jointly determined with private saving rate, is next to impossible.

Loayza et al. (2000b) and others try to circumvent this problem by using "internal instruments", which are lagged values of the explanatory variables. However, this approach is also a limited solution to the endogeneity problem and not a panacea at all, since using lagged values of the explanatory variables as instrumentals renders explanatory variables only weakly exogenous at best, not strictly exogenous in any sense. That is, explanatory variables "can be affected by current and past realizations of the saving rate but must be uncorrelated with future realizations of the error term" (Loayza et al., 2000b).

Moreover, while using lagged values as instrumental variables still allows for reverse causality and does not eliminate endogeneity problem satisfactorily, it also restricts explanatory power of the saving behavior model (see Schultz, 2005). Because of these reasons, we tried to employ both Ordinary Least Squares (OLS), and Instrumental Variables Technique (IV) by using "internal instruments" as did Loayza et al. (2000b). Unfortunately, although we experimented with different IV models in which we used lagged values as instrumental variables, these experiments failed to yield a robust estimation. Indeed, as Higgins (1998) puts it,"[t]he exogeneity of the chosen instrument set is crucial: recent research suggests that the degree of inconsistency of 2SLS may exceed that of OLS given even a small degree of endogeneity." Therefore, we decided to drop internal instruments approach altogether and implemented OLS estimations and formed a VEC model in order to circumvent possible endogeneity bias. 
Augmented Dickey-Fuller (ADF) test was conducted to analyze the data, revealing the presence of a unit root in the data for all of the variables, except income growth and real interest rate, which were found to be stationary in their levels. In their first difference, all of the variables except urbanization rate, social security level and terms of trade were stationary. These variables (designated in Table 1 below with asterisks) were stationary only in their second difference.

Table: 1

ADF Unit Root Tests

\begin{tabular}{|c|c|c|c|c|}
\hline & \multicolumn{2}{|c|}{$\mathbf{I}(\mathbf{0})$} & \multicolumn{2}{|c|}{$\mathbf{I}(\mathbf{1})$} \\
\hline Variable & t-stat. & Prob. & t-stat. & Prob. \\
\hline Private Saving (-1) & $-2,96$ & 0.5406 & $-2,97$ & 0.0022 \\
\hline Income Growth & $-2,96$ & 0.0000 & $-2,97$ & 0.0000 \\
\hline Income Level & $-2,96$ & 0.9562 & $-2,97$ & 0.0001 \\
\hline Real Interest Rate & $-2,96$ & 0.0000 & $-2,97$ & 0.0000 \\
\hline Credit to GDP Ratio & $-2,96$ & 0.9981 & $-2,97$ & 0.0163 \\
\hline M2 to GDP Ratio & $-2,97$ & 0.9784 & $-2,97$ & 0.0000 \\
\hline Old Dependency Ratio & $-3,00$ & 0.9794 & $-3,00$ & 0.0017 \\
\hline Youth Dependency Ratio & $-3,00$ & 0.3286 & $-3,00$ & 0.0132 \\
\hline Urbanization Rate* & $-2,97$ & 0.6411 & $-2,97$ & 0.0002 \\
\hline Inflation Rate & $-2,96$ & 0.2159 & $-2,97$ & 0.0000 \\
\hline Social Security Level* & $-2,99$ & 0.9999 & $-2,99$ & 0.0048 \\
\hline Public Saving Level & $-2,96$ & 0.5181 & $-2,97$ & 0.0002 \\
\hline Current Account Balance & $-2,96$ & 0.1031 & $-2,97$ & 0.0000 \\
\hline Terms of Trade* & $-3,00$ & 0.4244 & $-2,64$ & 0.0710 \\
\hline
\end{tabular}

\subsection{OLS Estimations}

The OLS estimation results are presented in Table 2. Of the 14 variables included in the model as potential determinants of saving behavior, coefficients of eight variables reached a significance level of at least $5 \%$.

Although several studies reported a possible link between the private saving rate of preceding period and the current private saving rate, no statistically significant relationship was identified in the OLS estimation, which indicates that inertia is not a determining factor. This result, however, is consistent with the precipitous decline of the Turkish private saving rate in the 2000 s, since it has not returned to previous levels.

Table: 2

OLS Estimation Results (Full Model)

\begin{tabular}{|c|c|c|c|c|}
\hline Variable & Coefficient & Std.Error & t-stat & Prob. \\
\hline Private Saving (-1) & 0,226 & 0,128 & 1,767 & 0,115 \\
\hline Income Growth & $-0,092$ & 0,063 & $-1,475$ & 0,178 \\
\hline Income Level & 0,008 & 0,009 & 0,888 & 0,400 \\
\hline Real Interest Rate** & 0,128 & 0,042 & 3,033 & 0,016 \\
\hline Credit to GDP Ratio** & $-0,342$ & 0,106 & $-3,223$ & 0,012 \\
\hline M2 to GDP Ratio & 0,049 & 0,086 & 0,562 & 0,59 \\
\hline Old Dependency Ratio & 3,729 & 3,161 & 1,180 & 0,272 \\
\hline Youth Dependency Ratio** & 2,617 & 0,829 & 3,157 & 0,013 \\
\hline Urbanization Rate & $-0,270$ & 1,122 & $-0,241$ & 0,816 \\
\hline Inflation Rate* & 0,151 & 0,023 & 6,556 & 0,0002 \\
\hline Social Security Level** & $-1,122$ & 0,303 & $-3,702$ & 0,006 \\
\hline Public Saving Level* & $-0,754$ & 0,156 & $-4,836$ & 0,001 \\
\hline Current Account Balance*** & $-0,564$ & 0,225 & $-2,507$ & 0,037 \\
\hline Terms of Trade* & 0,236 & 0,060 & 3,944 & 0,004 \\
\hline R-squared & 0,96 & & & \\
\hline Adjusted R-squared & 0,89 & & & \\
\hline
\end{tabular}

Note: (*) and (**) indicate statistical significance levels at \%1 and $5 \%$ respectively. 
In addition, neither income level nor income growth seem to have a discernable effect on private saving rate in Turkey, in contrast to the findings of Matur et al. (2012), in which they found statistically positive, albeit a weak relationship between income level and private saving rate and statistically negative, and again a weak relationship between income growth and private saving rate.

The coefficients for these variables in our estimation are not only insignificant, but also very close to zero. This is no surprise because, theoretically, the effect of income growth on private saving rate is not unambiguous, while the effect of income level on private saving rate cannot be captured effectively in a time-series analysis, since these kinds of important and high-magnitude variables tend to change very slowly. On the other hand, we must approach this result with caution, since income level and income growth are highly associated with private saving level and all these variables seem to be jointly determined.

Although most empirical studies have failed to find a relationship between real interest rate and private saving rate, OLS estimation found a weak but significantly positive relationship between them, implying that the substitution effect surpasses the income effect in the Turkish case. The coefficient of real interest rate is 0.13 , which is very close to 0.15 of the estimation of Matur et al. (2012).

As previously mentioned, at the same time as private saving rate in Turkey plummeted, credit volume increased significantly, making this one of the most promising factors for explaining the reduction in private saving rates. Expectedly, OLS estimation found statistically significant negative relationship between credit volume and private saving rate. The coefficient is -0.34 , that is, one percent change in the credit volume tends to decrease private saving rate 0.34 percent.

On the other hand, the coefficient of M2 to GDP ratio was found to be insignificant. This is no surprise given that the effect of monetization level on private saving rate is ambiguous. That is, monetization level can be conceived as both a measure of financial depth, which implies a positive relationship between private saving rate and monetization level, and of borrowing constraint which implies a negative one.

Of the demographic variables, only the coefficient for the youth dependency ratio was significant, suggesting an implausible positive influence on private saving rate. As with income variables demographic variables are high-magnitude and change very slowly, so it is not unusual that the coefficients for the old dependency and urbanization ratios were insignificant. Moreover, we should be cautious with the results found for the youth dependency ratio for the same reason; the coefficient for this variable seems significant, but its sign is positive and its magnitude is very high, which seems unlikely. The result may instead reflect the fact that fertility rates in Turkey declined over the same period as private saving rates, meaning that the proportion of young people in the Turkish population shrank accordingly. The significant positive relationship between saving rate and youth dependency ratio found in this research is therefore should be mere correlation, rather than causation. 
As mentioned above, higher inflation rates imply uncertainty, encouraging people to save more, while higher levels of social security reduce uncertainty and result in people saving less. This means that the coefficient for inflation rate should be positive, while the coefficient for social security level should be negative. Indeed, of these uncertainty variables, the coefficient for the inflation rate variable is significant with a positive sign and the coefficient for social security levels is significant with a negative sign. The coefficient of inflation rate variable is 0.15 , which is relatively low, yet plausible. The coefficient of social security level is -1.12 , which is relatively high, but totally expected since social security is a major complement to precautionary saving.

In relation to public and private saving, the theory and evidence suggested that there should be a negative relationship. This was confirmed in this study, with a negative relationship between these variables indicating that public and private saving are partly complementary to each other. The coefficient is -0.75 , implying that one percent increase in public saving rate decreases private saving rate 0.75 percent. This estimation is almost the same with the IMF estimation of 0.73 (Fletcher, Keller, Brooks, Lombardo, \& Meier, 2007), and very close to the coefficient of 0.63 estimated Van Rijckeghem (2010).

Of the foreign trade variables, the coefficient (-0.56) for current account balance was statistically significant with a negative sign, as opposed to our expectations. As mentioned previously, caution is required when interpreting this result, because both current account balance and private saving rate are products of numerous economic variables and they are jointly determined. As such, the negative relationship between these should be correlation, rather than causation. The coefficient $(0.24)$ for terms of trade, meanwhile, is significant with a positive sign, as expected, since favorable terms of trade lead to increased income and (hence) saving.

Table: 3

OLS Estimation Results (Without Demographics and Income Variables)

\begin{tabular}{|c|c|c|c|c|}
\hline Variable & Coefficient & Std.Error & t-Stat & Prob. \\
\hline Private Saving (-1) & 0,0223 & 0,128 & 0,176 & 0,863 \\
\hline Real Interest Rate ${ }^{* *}$ & 0,084 & 0,040 & 2,125 & 0,05 \\
\hline Credit to GDP Ratio*** & $-0,198$ & 0,071 & $-2,782$ & 0,014 \\
\hline M2 to GDP Ratio & 0,025 & 0,081 & 0,308 & 0,763 \\
\hline Inflation Rate* & 0,113 & 0,021 & 5,412 & 0,0001 \\
\hline Social Security Level* & $-1,054$ & 0,310 & $-3,401$ & 0,004 \\
\hline Public Saving Level* & $-0,752$ & 0,145 & $-5,198$ & 0,0001 \\
\hline Current Account Balance & $-0,230$ & 0,133 & $-1,721$ & 0,106 \\
\hline Terms of Trade* & 0,156 & 0,051 & 3,073 & 0,008 \\
\hline R-squared & 0,88 & & & \\
\hline Adjusted R-squared & 0,81 & & & \\
\hline
\end{tabular}

Note: $(*)$ and $(* *)$ indicate statistical significance levels at \%1 and $5 \%$ respectively.

Finally, we constructed a second OLS estimation, this time without the "highmagnitude" and "slowly-changing" demographic and income variables. As in the original analysis, the coefficients for the previous period's private saving rate and M2 to GDP ratio were insignificant. Moreover, all variables with significant coefficients in the original analysis have significant coefficients here too, other than current account balance, which now has an insignificant coefficient. This may reflect the caution expressed above regarding the nature of the relationship between current account balance and private saving rate. On 
the other hand, the magnitudes of the coefficients decreased to some extent in the second estimation. Specifically, while only the coefficient of public saving rate stayed almost the same, the coefficient of real interest rate decreased from 0.12 to 0.08 , credit volume to GDP ratio shrank from 0.34 to 0.20 , inflation rate decreased from 0.15 to 0.11 , social security level declined from -1.12 to -1.05 and terms of trade dwindled from 0.24 to 0.16 .

\subsection{VEC Model}

In this section, we formed a VEC model in complementary for OLS estimations represented above and to capture long-term relationship between private saving rate and other variables. Due to degree of freedom concerns, we restricted variables to five in the VEC model. First, we dropped I(2) variables, namely; terms of trade, social security level and urbanization rate in the first place, since these variables are not I(1), so not appropriate for the VEC model. Second, we experimented with all the remaining variables, which are integrated in their first difference, or I(1), to form VEC models. In the end, demographic variables, income variables, and real interest rate and M2 to GDP variables failed to enter the VEC models. This is no surprise given that coefficients of these variables were not significant in the original OLS estimation. One exception was real interest rate variable, which had a statistically significant coefficient in the OLS estimations. With the remaining variables, which had statistically significant coefficients in the OLS estimations, namely private saving rate, public saving rate, inflation rate, credit to GDP ratio, and current account balance variables, we managed to form statistically robust a VEC model. However, one partial exception was current account balance variable, which has a significant coefficient in the first OLS model, but insignificant one in the second OLS estimation.

So, our VEC model takes the following form:

$$
S_{t}=\beta_{1} P S_{t}+\beta_{2} I_{t}+\beta_{3} C A_{t}+\beta_{4} C_{t}
$$

Where, S denotes for private saving rate, PS refers to public saving rate, I is inflation rate, $\mathrm{CA}$ denotes to current account balance and finally $\mathrm{C}$ refers to credit volume.

We implemented the Johansen Cointegration test in order to reveal whether there is a long-run relationship among variables in the model. As can be seen in Table 3, there is at least one long-run relationship between the series at the $5 \%$ significance level.

Table: 4

Johansen Cointegration Test

\begin{tabular}{cccc} 
& \multicolumn{2}{c}{ Trace } & Probability \\
\hline & 0.05 Crit. Value & 0.0012 \\
\hline & 69.82 & \\
\hline & Mrace Statistic & Maximum Eigenvalue & Probability \\
\hline & Trace Statistic & 0.05 Crit. Value & 0.0093 \\
\hline
\end{tabular}

The lag length of the variables was set at 1, based on the Akaike information criterion, or AIC. This lag length is reasonable given that yearly data was employed for the model. 
While the numbers in the round brackets denote the standard errors of the coefficients; the numbers in the square brackets refers to the t-statistics.

$$
\begin{aligned}
& S_{t}=20.11-0.40 P S_{t}+0.07 I_{t}+0.78 C A_{t}-0.07 C_{t} \\
& \left(\begin{array}{llll}
0.03) & (0.005) & (0.09) & (0.03) \\
{[11.63]} & {[-14.00]} & {[-9.03]} & {[2.74]}
\end{array}\right.
\end{aligned}
$$

In the estimation output of the VEC model, all the coefficients are significant at the $5 \%$ significance level. Moreover, the error correction term of the model has the correct negative sign and is statistically significant, which is a further support of a cointegration relationship between the variables. That indicates there is a long run relationship between these variables. The estimation output shows the reactions of the dependent variables to changes in the independent variables.

However, in order to analyze the interdependencies between private saving rate and other variables, and capture full dynamics of the model, we must use a more informative method, that is general impulse-response analysis, or GIRF (Albertus, Van Eyden, \& Gupta, 2009). This method was developed by Koop, Pesaran, and Potter (1996), which "provides a theoretically consistent account of the interdependencies of idiosyncratic shocks" (Pesaran, Schuermann \& Treutler \& Weiner, 2003).

\section{Figure: 1}

\section{Generalized Impulse-Response Functions}

Response to Generalized One S.D. Innovations

Response of PRIVATE_SAVING to PUBLIC_SAVING

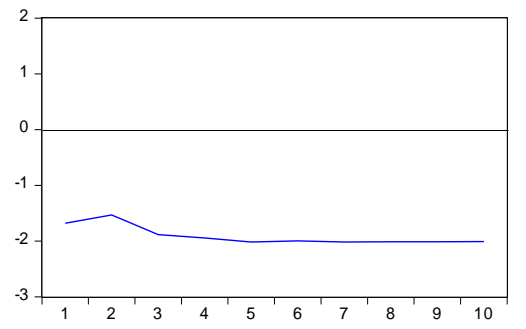

Response ofPRIVATE_SAVING to CURRENT_ACCOUNT_BALANCE

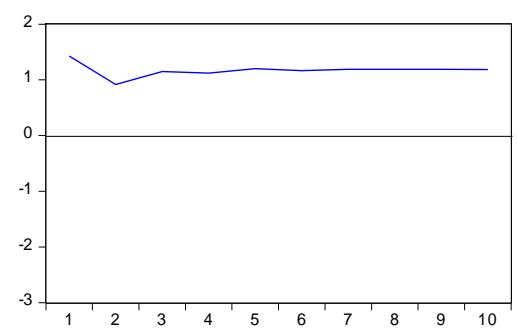

Response of PRIVATE SAVING to INFLATION

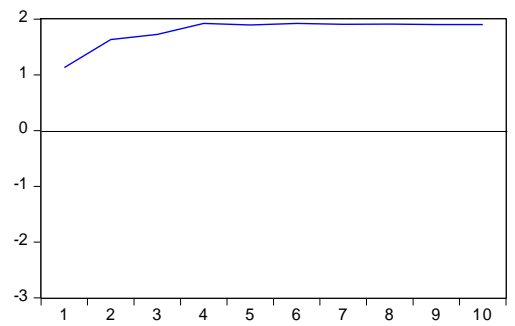

Response of PRIVATE_SAVING to CREDIT

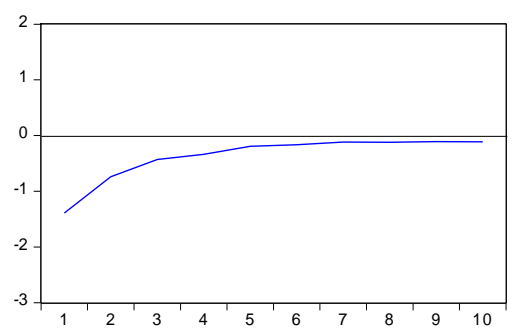


The generalized impulse-response functions in the Figure 1 show the dynamic responses of private saving rate to one standard deviation change in other variables in the VEC model. The results are largely in line with the OLS estimations above. Firstly, public saving rate has a (continuously) negative impact on the private saving rate. Secondly, a change in the inflation rate has an enduring and positive effect on the private saving rate. Thirdly, although a change in the credit volume has a negative influence on the private saving level, this effect quickly diminishes and comes to near-zero level after six years. Lastly, a positive shock in the current account balance results in an increase in the private saving rate, as expected, since a recovering current account balance tends to increase private saving rate.

\section{Conclusion}

This paper represents an attempt to ascertain the determinants of private saving levels in Turkey and to examine the nature of saving behavior in general. OLS estimations indicate a negative relationship between private saving rate and a number of variables, including public saving level, borrowing constraints (e.g., credit to GDP ratio), and social security level. On the other hand, OLS estimations found a positive relationship between private saving rate and real interest rate, inflation rate and terms of trade variables.

In order to circumvent possible endogeneity problem and confirm (or deny) findings obtained in the OLS estimations we constructed a VEC model. We found a long run relationship between private saving rate, public saving rate, inflation rate, credit volume to GDP ratio and current account balance. As in line with the OLS estimations, we found public saving rate and credit volume have a negative impact on private saving rate. However, while the effect of credit volume to GDP ratio on private saving rate diminishes in time, the effect of public saving rate on it seems to be permanent. In addition, VEC model reveals that inflation rate and current account balance positively affects private saving rate in the long run.

Taken together, these results suggest that there is a trade-off between private and public saving rate. Furthermore, uncertainty (e.g., higher inflation rates, lower levels of social security) tends to increase private saving, while easy access to credit tends to decrease it for a certain amount of time. Finally, favorable terms of trade may increase income, thereby encouraging private saving, while current account balance have a positive effect on private saving rate. (However, we should note that we found evidence for terms of trade and social security level variables in only OLS estimations and we could not test these variables in the VEC analysis, since these variables were not I(1). So we must approach with caution to those findings.)

Turkish private saving levels plunged in the 2000s. Along with this, many aspects of Turkish society and the country's economy experienced major transformations over the same period: public saving rate turned positive, inflation rate decreased sharply, credit volume increased steeply, current account balance deteriorated immensely and social 
security level expanded tremendously. In light of the findings in this paper, one can say that all of these factors played an important role in determining private saving level in Turkey.

\section{References}

Agrawal, P. \& P. Sahoo \& R.K. Dash (2009), "Savings Behaviour in South Asia”, Journal of Policy Modeling, 31(2), 208-224.

Albertus, H. \& R. Van Eyden \& R. Gupta (2009), "Linking Global Economic Dynamics to A South African-Specific Credit Risk Correlation Model”, Economic Modelling, 26(5), 10001011.

Arellano, M. \& O. Bover (1995), "Another Look at the Instrumental Variable Estimation of ErrorComponents Models", Journal of Econometrics, 68(1), 29-51.

Attanasio, O.P. \& L. Picci \& A.E. Scorcu (2000), "Saving, Growth, and Investment: A Macroeconomic Analysis Using A Panel of Countries", Review of Economics and Statistics, 82(2), 182-211.

Bayoumi, T. (1993), "Financial Deregulation and Household Saving", The Economic Journal, 103(421), 1432-1443.

Bérubé, G. \& D. Côté (2000), Long-term Determinants of the Personal Savings Rate: Literature Review and Some Empirical Results for Canada, Bank of Canada.

Bosworth, B. \& G. Chodorow-Reich (2007), Saving and Demographic Change: The Global Dimension, available at SSRN: <http://ssrn.com/abstract=1299702> or <http://dx.doi.org/10.2139/ssrn.1299702>, 28.01.2017.

Carroll, C.D. \& D.N. Weil (1994), "Saving and Growth: A Reinterpretation”, Carnegie-Rochester Conference Series on Public Policy, 40, 133-192.

Edwards, S. (1996), "Why are Latin America's Savings Rates So Low? An International Comparative Analysis", Journal of Development Economics, 51(1), 5-44.

Feldstein, M. (1980), "International Differences in Social Security and Saving", Journal of Public Economics, 14(2), 225-244.

Feldstein, M. \& C. Horioka (1980), "Domestic Saving and International Capital Flows", The Economic Journal, 90(358), 314-329.

Fletcher, K. \& C. Kelleri \& P. Brooks \& D. Lombardo \& A. Meier (2007), "Safe to Save Less? Assessing the Recent Decline in Turkey's Private Saving Rate", IMF Selected Issues Paper, 7(364).

Friedman, M. (1957), A Theory of the Consumption Function, Princeton: Princeton University Press.

Grigoli, F. \& A. Herman \& K. Schmidt-Hebbel (2014), "World Saving”, IMF Working Papers.

Hevia, C. (2010), Saving in Turkey: An International Comparison, Background Study for the CEM, Ankara: World Bank.

Higgins, M. (1998), “Demography, National Savings, and International Capital Flows”, International Economic Review, 343-369.

Hondroyiannis, G. (2006), "Private Saving Determinants in European Countries: A Panel Cointegration Approach", The Social Science Journal, 43(4), 553-569.

Horioka, C.Y. \& T. Yin (2009), Household Saving Rates and Social Benefit Ratios: Country Comparisons, Paper presented at the Effects of Social Policy on Domestic Demand: Annual Conference. 
Hüfner, F. \& I. Koske (2010), Explaining Household Saving Rates in G7 Countries, Paris: OECD Publishing.

Jappelli, T. \& M. Pagano (1989), "Consumption and Capital Market Imperfections: An International Comparison", The American Economic Review, 79(5), 1088-1105.

Jermias, J. \& F. Yigit (2013), "Budgetary Participation in Turkey: The Effects of Information Asymmetry, Goal Commitment, and Role Ambiguity on Job Satisfaction and Performance", Journal of International Accounting Research, 12(1), 29-54.

Keynes, J.M. (1936), The General Theory of Interest, Employment and Money, London: Macmillan.

Kim, S. \& J.W. Lee (2008), "Demographic Changes, Saving, and Current Account: An Analysis Based on A Panel VAR Model", Japan and the World Economy, 20(2), 236-256.

Koop, G. \& M.H. Pesaran \& S.M. Potter (1996), "Impulse Response Analysis in Nonlinear Multivariate Models", Journal of Econometrics, 74(1), 119-147.

Kuznets, S. (1946), National Income: A Summary of Findings, New York: NBER Books.

Li, H. \& J. Zhang \& J. Zhang (2007), "Effects of Longevity and Dependency Rates on Saving and Growth: Evidence from A Panel of Cross Countries", Journal of Development Economics, 84(1), 138-154.

Loayza, N., K. Schmidt-Hebbel and L. Servén (2000a), "Saving in developing countries: an overview”, The World Bank Economic Review, 14(3), 393-414.

Loayza, N. \& K. Schmidt-Hebbel \& L. Servén (2000b), "What Drives Private Saving Across The World?", Review of Economics and Statistics, 82(2), 165-181.

Lührmann, M. (2003), "Demographic Change, Foresight and International Capital Flows", MEA Discussion Papers, 2003(38).

Masson, P.R. \& T. Bayoumi \& H. Samiei (1998), "International Evidence on the Determinants of Private Saving", The World Bank Economic Review, 12(3), 483-501.

Matur, E.P. \& A. Sabuncu \& S. Bahçeci (2012), "Determinants of Private Saving and Interaction between Public and Private Savings in Turkey", Topics in Middle Eastern and North African Economies, (14), 102-125.

Modigliani, F. (1986), "Life Cycle, Individual Thrift, and the Wealth of Nations", The American Economic Review, 76(3), 297-313.

Modigliani, F. \& R.D. Bartel (1987), "The Key to Saving Is Growth, Not Thrift”, Challenge, 30(2), 24-29.

Modigliani, F. \& A. Sterling (1981), "Determinants of Private Saving with Special Reference to the Role of Social Security: Cross Country Tests”, in: F. Modigliani \& R. Hemming (eds.), The Determinants of National Saving and Wealth, London: MacMillan, 24-55.

Mohan, R. (2006), "Causal Relationship between Savings and Economic Growth in Countries with Different Income Levels", Economics Bulletin, 5(3), 1-12.

Ozcan, K.M. \& A. Gunay \& S. Ertac (2003), "Determinants of Private Savings Behaviour in Turkey", Applied Economics, 35(12), 1405-1416.

Pesaran, M. \& T. Schuermann \& B.J. Treutler \& S.M. Weiner (2003), "Macroeconomic Dynamics and Credit Risk: A Global Perspective", CESifo Working Paper Series (995).

Ramajo, J. \& A. García \& M. Ferré (2006), "Explaining Aggregate Private Saving Behaviour: New Evidence from A Panel of OECD Countries", Applied Financial Economics Letters, 2(5), 311-315. 
Schmidt-Hebbel, K. \& S.B. Webb \& G. Corsetti (1992), "Household Saving in Developing Countries: First Cross-country Evidence", The World Bank Economic Review, 6(3), 529547.

Schrooten, M. \& S. Stephan (2003), "Back on Track? Savings Puzzles in EU-Accession Countries", ENEPRI Working Paper, No. 23, October 2003.

Schultz, T.P. (2005), Demographic Determinants of Savings: Estimating and Interpreting the Aggregate Association in Asia, Economic Growth Center of Yale University (901).

Van Rijckeghem, C. (2010), "Determinants of Private Saving in Turkey: An Update”, Boğaziçi Üniversitesi İktisat Bölümü Çalışma Tebliği, 4.

Zeldes, S.P. (1989), “Consumption and Liquidity Constraints: An Empirical Investigation”, The Journal of Political Economy, 97(2), 305-346. 
Tatliyer, M. (2017), "Determinants of Private Saving Level:

Evidence from Turkey", Sosyoekonomi, Vol. 25(32), 149-167. 